\title{
An Assessment of Factors Affecting Budget Utilization (Case of East Wollega Administrative Zone)
}

\author{
HASHIM TUNE SADO (MSc) \\ Wollega University, College of Business and Economics, Department of Accounting and Finance \\ P.O. Box: 395, Nekemte, Ethiopia
}

\author{
Abbreviations and Acronyms \\ MoFED-Ministry of Finance and Economic Development \\ MoFED-Finance and Economy Development \\ MEFF-Macro-Economic and Fiscal Framework \\ SPSS -Statistical Package for the Social Science
}

\begin{abstract}
The main purpose of this study is to asses' factors affecting budget utilization in East Wollega administrative Zone with special references to some selected Woredas. In order to maintain the desired objectives descriptive survey research is designed for the study. The main data of this study was both primary and secondary data which was analyzed by applying descriptive statistics focusing on central tendency, arithmetic mean, and standard deviation, standard error of mean with disparity between the two groups and, independent t-test employed SPSS version 20.00. The results reveal that, there are many factors affecting budget utilizations such as; inflation, tax compliance, government policy and structural factors.
\end{abstract}

Keywords: Utilization, Factors, Budget, Investigation, Affect.

DOI: $10.7176 / \mathrm{RJFA} / 10-19-01$

Publication date:October $31^{\text {st }} 2019$

\section{INTRODUCTION}

In the world today, organizations have developed a variety of processes and techniques designed to contribute to the planning and control functions. One of the most important and widely used of these processes is budgeting. Budgeting involves the establishment of predetermined goals, the reporting of actual performance results and evaluation of performance in terms of the predetermined goals. Then, Budgeting is defined as a form of financial planning and as such budget is utilized to impose the strategy of a country. Consequently, a budget is composed of different functional budgets that could help a country for development such as agriculture, technology, tourism and other (Smith and Mcgeary, 1997).

Budget has multiple functions such as: control of public resources, planning for the future, allocation of resources and management of resources. However, the relative strength of each function depends on the current view of the function of budgeting and budgeting tools and techniques, but also depends on the strength of particular organizations and/or institutional arrangements to support these functions (World Bank, 1998)

The public budget planning is a process by which government sets the level of expenditure, collects revenues and allocates the spending of resources among all sectors to meet national goals (Shah, 2008). Budget implementation on the other hand is the actual execution of the budget and application of funds to the planned activities. During the fiscal year, however, not all allocated budgets are used as per the proposed plan. These could be cases where the approved funds may not be enough to fully accomplish the intended goal. In other instances, the amount allocated to a project may be more than what the project can consume. The disparities between the budget allocated and actual expenditure arise due to multiplicity of factors and improper costing of county functions (Rotich and Ngahu, 2015). The budget cycle needs to be tracked and at every stage the factors that could be affecting the utilization of the budget analyzed.

In the Ethiopia public sector, the budget implementation period or the financial years run from 1st July to 31 st June. During this period, a lay down medium term expenditure framework budget cycle is followed in the preparation and implementation of the national budget. Budget implementation is the real execution of the budget and application of funds to the planned activities. During the financial year, however, not all funds are expended as per the plan.

Budget utilization affected with intrinsic and extrinsic factors within the boundary of in and outside of the organization having the influence on the proper utilization of the budget. Hence, this study would attempt to assess factors affecting budget utilization in East Wollega administrative Zone desired to prove the problem in advance.

From the review of past research, most studies have concentrated on budget preparation, practice, transparency and accountability, and budget implementation in the public sectors, but as best of the researcher knowledge, little studies are conducted on identification of determinant factors affecting budget utilization in the study area. 
The proposed researches are trying to answer the following basic questions.

* What are the factors affecting budget utilization?

* To what extent does factors' affecting budget utilization?

* What possible measures should be taken to enhance factors affecting budget utilization?

* To evaluate the associations between factors affecting budget utilization?

The main objective of the study is to investigate the factors affecting budget utilization in East Wollega administrative Zone with special references of selected Woredas.

\section{Specific objectives}

To identify factors affecting budget utilization in East Wollega Zone selected woredas?

To determine to what extent the factors affecting budget utilization in east Wollega Administrative Zone?

To evaluate the associations between factors affecting budget utilization?

\section{Literature Review}

Overview of Budget

A budget is defined as an itemized summary of estimated expenditures for a given period along with proposals for financing them (Daniel, 2005). In the public service the main sources of finances include taxes levied directly or indirectly, fines and penalties, revenues from profit making state corporations, charges and fees on services rendered foreign aid and donations from development partners and internal and external borrowing. The monies raised are then applied in main government expenditure sectors such as the regional governments and the zonal sectors which further divide to the zonal offices and Woredas level offices for implementation. These are the points where budgets are to be utilized finally being affected by different level factors.

Generally, budget is a vital role to improve the coordination among the various units of the organization. So the organization overall performance depends on the budget with respect to financial plan for implementing the various decision.

\section{Budget Preparation}

In Ethiopia budget process is guided by a directive (financial calendar) issued by the ministry of Finance and Economy Development (MoFED) to all entities listed as public bodies. This directive has a schedule to make sure that planning and budgeting are prepared, approved, appropriated and executed so in line the pre-set development agendas (FDRE., 2009). Its preparation is often guided by a document known as the Macro- Economic and Fiscal Framework (MEFF) prepared by MoFED. The MEFF provides, among others, forecasts of government revenue and expenditure; expenditure financing, the division of total expenditure between federal and regional, and divide federal expenditures between recurrent and capital expenditures for the next three years which the program budget is planned for (MoFED, 2010). Furthermore, preparation of the budget usually takes many months and involves all public institutions: the Ministry of Finance manages the process; the Cabinet/President sets or approves the policy priorities, line ministries plan and advocate for their resource needs and the legislature reviews and approves the final plan. Preparation is at the heart of the political process: it is the decision on how to allocate the state's limited resources to competing demands.(A., 2008).

\section{Budget Utilization}

Right after the approval of budget prepared by the legislature, the government embarks on the challenging task of spending funds. Utilizing public funds effectively to meet stated policy objectives while ensuring value for money is often just as challenging than planning how to spend it. Several reviews of Public Financial Management performance in developing countries show that countries score significantly better on budget preparation than on budget utilizing. Budget utilization is the phase where resources are used to implement policies incorporated in the budget. As they argued, it is possible to utilize badly a well-prepared budget; it is not possible to utilize well a badly prepared budget.(Schiavo-Campo, 1999)

\section{Empirical Reviews related to factors affecting budget utilisation}

According to (Tafa, 2016), referring shah 2008 and World Bank, 1998, Government organizations plan their activities as well as the budget to fulfill the public interest. In order to sustain economic growth and reduce poverty, it is important to link physical planning, budgeting policy priorities. Failure to link policy, planning and budgeting is an important factor contributing to poor budgeting outcomes at the macro, strategic and operational levels in developing countries.

As per (ABSHIRO, 2014) Strong system of internal control is very essential in achieving certain goals of an organization. Internal control includes all the procedures and actions taken by an organization in order to manage the expiating assets, ensure conformity with organizations policy and governmental rules, evaluate operating 
efficiency and ensure precise and reliable operating data and accounting records. According to Charles Kip sang, 2015 after conducting a research on kericho County government in kenya suggested that there exist a moderately strong Negative and statistically significant relationship between inflation and budget utilization.(Rotich, 2015)

Charles Kip sang, in addition to the factor Inflation rate he assessed, showed as inflation rate increases, budgetary estimation at the county government will decreases. This is because inflation leads to high budget errors and unemployment. Lastly, unexplained increase in price of VAT added goods will affect the real value of money in the county government as such his findings revealed that there existed a positive and statistically significant relationship between tax compliance and budget utilization, a weak negative correlation was observed between VAT policy and budget utilization. (Rotich, 2015)

According to Christine, 2012, lack of alignment between the organizational structure and structure of performance reporting requirements, value and usefulness of performance information were found to undermine the budget utilization.(KAJUJU, 2012)

Dejene Tafa, 2016 has also found that organizational structure induced factors such as lack of effective budget monitoring, lack of a decentralized budget administration system, absence of clear hierarchy in the administration of budgets, structural relationship between different department and lack of effective communication are some of the main factors that affect public budget utilization in Ethiopia(Tafa,2016) .

\section{Conceptual Framework}

As outlined in figure 1, In order to support the objectives of the study the researcher of this study has to recognize the following conceptual framework of the study.

\section{Figure 1. Conceptual framework}

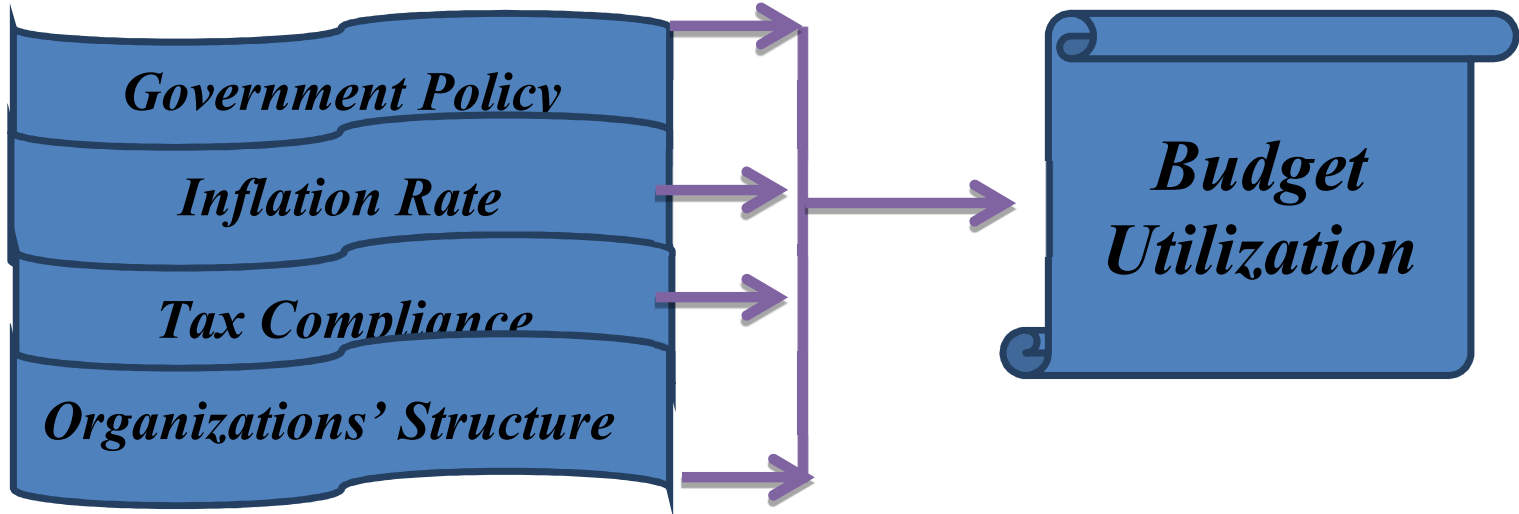

\section{Research Approaches}

In order to achieve the objective of this study, the researcher used both quantitative and qualitative method of research approach with descriptive survey research design. Thus, the researcher examined major factors affecting budget utilization in East Wollega Zone with special reference to some selected Woredas.

\section{Sample and Sampling Techniques}

Accordingly from the 21 zones found in Oromia region, one zone (East Wollega zone which comprise 17 woredas) and from the 17 woredas found in East wollega zone 6 woredas and nekemte city administration are selected as centers of the study on the basis of convenience sampling (purposive sampling) method. In designing a sample, the researcher used different basic factors, such as availability of data, transportation service access, distance of woredas from the zone and the like.

The total number of target population in the selected woredas is 280 Top mangment, Auditors, woredas finance and budget officials and sector finance budget officials. From this population the researcher selected 140 $(50 \%)$ staffs by their position and relations to budget process (Budget users and Disbursement team). The purposive selection was based on the assumption that these people had broad knowledge of understanding the whole concept of budget and its importance in an organization.

\section{Data Collection Tools}

Both primary and secondary data sources were used in the study. The primary data was collected from the woredas and sectors budget officials, top managers, audit experts and other department. The researcher used such instruments as self-administered questionnaires and semi-structured interviews to collect primary data from the respondents. Secondary data were gathered from document analysis of BOFED and WOFED, audited annual reports, proclamations, and regulations and different related literatures such as books, journals, magazines, research reports, internet and others to support primary data. 


\section{Methods of Data Analysis and Presentation}

To analyze and interpret the data obtained from respondent's descriptive statistics were used, with frequency, percentage, arithmetic mean, standard deviation and independent $\mathrm{T}$ - test and p-values are used to compare the data amongst the participants by using SPSS version 20. Furthermore, qualitative data that are gathered from woredas finance managers and others that are used to supplement the data gathered through questionnaire were organized, summarized and interpreted in words qualitatively.

\section{Results and Discussion}

The selected sample size of this study was 140 employees for whom the questionnaires distributed in the six sample woredas and Nekemte city found in East wollega zone. Out of these, 133(95\%) copies filled and returned. The information obtained through interview and document analyses used as a complementary data for analysis. The characteristics of the subjects were their position and knowledge about budget.

\section{Factors affecting Budget utilization}

This part deals with the procedure of data analysis and interpretation concerning investigation of factors that affect budget utilization in some selected Woredas of East Wollega zone.

\section{Response Scale}

\begin{tabular}{|l|l|l|l|l|}
\hline 1 & 2 & 3 & 4 & 5 \\
\hline Strongly Disagree & Disagree & Neutral & Agree & Strongly Agree \\
\hline
\end{tabular}

Table 1 Respondents View on Structural Factors affecting budget utilization

\begin{tabular}{|c|c|c|c|c|c|c|c|}
\hline \multirow[t]{2}{*}{ Factors criteria on budget utilisation } & \multicolumn{5}{|c|}{ Response scale } & \multicolumn{2}{|c|}{ Descriptive Statistics } \\
\hline & 1 & 2 & 3 & 4 & 5 & Mean & $\begin{array}{c}\text { Std. } \\
\text { Deviation }\end{array}$ \\
\hline $\begin{array}{l}\text { 1. There is a clear hierarchy of } \\
\text { budgets administration in your } \\
\text { organization. }\end{array}$ & $\begin{array}{l}14 \\
10.5 \%\end{array}$ & $\begin{array}{l}68 \\
51.1 \%\end{array}$ & $\begin{array}{l}42 \\
31.6 \%\end{array}$ & $\begin{array}{l}9 \\
6.8 \%\end{array}$ & - & 2.3459 & .75924 \\
\hline $\begin{array}{l}\text { 2. There is a proper involvement of } \\
\text { auditor in all office major projects. }\end{array}$ & $\begin{array}{l}10 \\
7.5 \%\end{array}$ & $\begin{array}{l}49 \\
36.8 \%\end{array}$ & $\begin{array}{ll}48 \\
36.1 \%\end{array}$ & $\begin{array}{l}20 \\
15 \%\end{array}$ & $\begin{array}{l}6 \\
4.5 \%\end{array}$ & 2.7218 & .96416 \\
\hline $\begin{array}{l}\text { 3. There is smooth and facilitating } \\
\text { structural relationship between } \\
\text { different departments in the } \\
\text { organization associated with } \\
\text { budget use. }\end{array}$ & $\begin{array}{l}13 \\
9.8 \%\end{array}$ & $\begin{array}{l}64 \\
48.1 \%\end{array}$ & $\begin{array}{l}26 \\
19.5 \%\end{array}$ & $\begin{array}{l}28 \\
21.1 \%\end{array}$ & $\begin{array}{l}2 \\
1.5 \%\end{array}$ & 2.5639 & .97974 \\
\hline $\begin{array}{l}\text { 4. There is continues and transparent } \\
\text { information flow among the } \\
\text { organizational elements related to } \\
\text { budget utilization. }\end{array}$ & $\begin{array}{l}21 \\
15.8 \%\end{array}$ & $\begin{array}{l}53 \\
39.8 \%\end{array}$ & $\begin{array}{ll}51 \\
38.3 \%\end{array}$ & $\begin{array}{l}8 \\
6 \%\end{array}$ & - & 2.3459 & .81692 \\
\hline $\begin{array}{l}\text { 5. There is a presence of the } \\
\text { evaluation of budget performance } \\
\text { at different levels of the } \\
\text { organization }\end{array}$ & $\begin{array}{l}9 \\
6.8 \%\end{array}$ & $\begin{array}{l}61 \\
45.9 \%\end{array}$ & $\begin{array}{l}46 \\
34.6 \%\end{array}$ & $\begin{array}{l}17 \\
12.8 \%\end{array}$ & - & 2.5414 & .82123 \\
\hline $\begin{array}{l}\text { 6. There is full involvement of the } \\
\text { line managers in planning and } \\
\text { budgeting utilization }\end{array}$ & $\begin{array}{ll}15 \\
11.3 \%\end{array}$ & $\begin{array}{l}58 \\
43.6 \%\end{array}$ & $\begin{array}{l}40 \\
30.1 \%\end{array}$ & $\begin{array}{l}14 \\
10.5 \%\end{array}$ & $\begin{array}{l}6 \\
4.5 \%\end{array}$ & 2.5338 & .98126 \\
\hline $\begin{array}{l}\text { 7. The delaines in approval of project } \\
\text { proposal by revenues managers did } \\
\text { not affected the utilization of } \\
\text { budgets }\end{array}$ & $\begin{array}{l}21 \\
15.8 \%\end{array}$ & $\begin{array}{l}64 \\
48.1 \%\end{array}$ & $\begin{array}{l}40 \\
30.1 \%\end{array}$ & $\begin{array}{l}8 \\
6 \%\end{array}$ & - & 2.2632 & .79672 \\
\hline $\begin{array}{l}\text { 8. There is proper ICT usage to } \\
\text { implement budgets utilization in } \\
\text { your revenues office. }\end{array}$ & $\begin{array}{l}24 \\
18 \%\end{array}$ & $\begin{array}{l}59 \\
44.4 \%\end{array}$ & $\begin{array}{l}32 \\
24.1 \%\end{array}$ & $\begin{array}{l}18 \\
13.5 \%\end{array}$ & - & 2.3459 & .96173 \\
\hline
\end{tabular}

\section{Source: Researcher's computation using SPSS (2018)}

As it can be seen from the summary of the above table 1 the mean score of all the responses for all the items under structural factors affecting the budget utilization have been seen to be poor in their status. This indicates that there is no clear hierarchy of administering budgets in these organizations with the poor involvement of the auditors in all the offices and it has been further stated that there is no smooth and facilitating structural relationship between 
different departments in the organization associated with budget utilization. The information flow among the departments have been shown to be poor and there is no better budget performance evaluation at different levels of the organization along with less involvement of the line managers in planning and budget utilization and dalliance in project proposal approval affect budget utilization.

Table 2 Respondents View on Budget Utilization Policy affecting budget utilization.

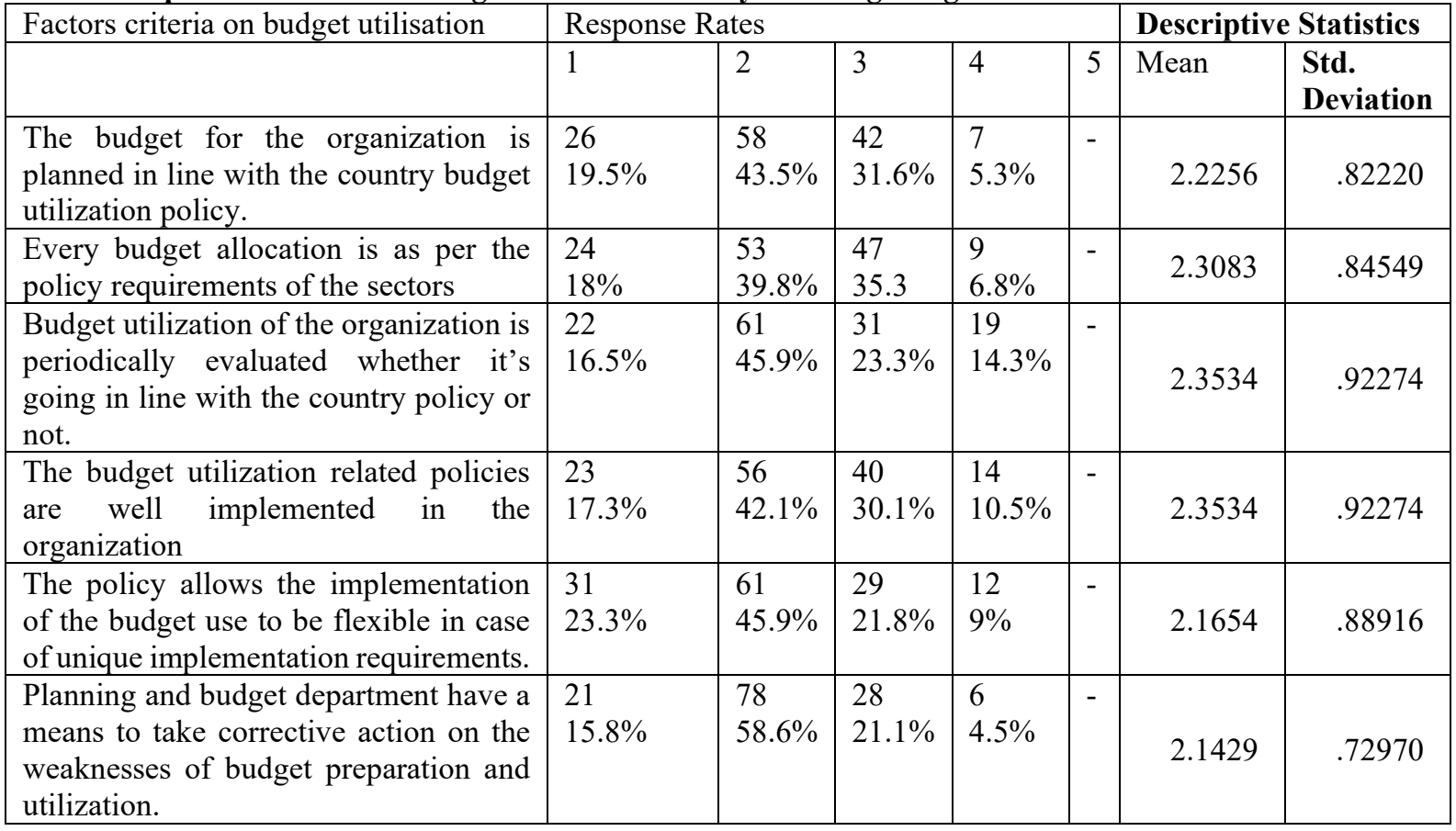

\section{Source: Researcher's computation using SPSS (2018)}

As depicts on table 2 above the mean score of all the responses for all the items under the budget utilization Policy have been seen to be poor in their status. This indicates that budget for the organization is not planned in line with the country budget utilization policy rather the budget is planned based on the sector proposal. Every budget allocation is not as per the policy requirements of the sectors and Budget utilization of the organization is not periodically evaluated whether it's going in line with the country policy or not. The budget utilization related policies are poorly implemented in the organization. As per the interview result and document review there is budget utilization policy in paper at regional, woreda and sectoral level but it is not practically considered in budget preparation and utilization.

Table 3 Respondents view on Tax compliance affecting budget utilization

\begin{tabular}{|c|c|c|c|c|c|c|c|}
\hline \multirow[t]{2}{*}{ Factors criteria on budget utilisation } & \multicolumn{5}{|c|}{ Response Rates } & \multicolumn{2}{|c|}{ Descriptive Statistics } \\
\hline & 1 & 2 & 3 & 4 & 5 & Mean & $\begin{array}{l}\text { Std. } \\
\text { Deviation }\end{array}$ \\
\hline $\begin{array}{l}\text { There is clear information for the tax } \\
\text { payers and stake holders about the } \\
\text { schedule and how of taxpaying. }\end{array}$ & $\begin{array}{l}24 \\
18 \%\end{array}$ & $\begin{array}{l}57 \\
42.9 \%\end{array}$ & $\begin{array}{l}40 \\
30.1 \%\end{array}$ & $\begin{array}{l}12 \\
9 \%\end{array}$ & & 2.3008 & .87026 \\
\hline $\begin{array}{l}\text { Adequate time and facilities are provided } \\
\text { to help tax payers comply with the } \\
\text { expectations of the government. }\end{array}$ & $\begin{array}{l}11 \\
8.3 \%\end{array}$ & $\begin{array}{l}62 \\
46.6 \%\end{array}$ & $\begin{array}{l}55 \\
41.4 \%\end{array}$ & $\begin{array}{l}4 \\
3 \%\end{array}$ & $\begin{array}{l}1 \\
0.8 \%\end{array}$ & 2.4135 & .71909 \\
\hline $\begin{array}{l}\text { There are a prepared responsibilities and } \\
\text { penalties for non-compliance of tax in } \\
\text { revenues office }\end{array}$ & $\begin{array}{l}21 \\
15.8 \%\end{array}$ & $\begin{array}{l}63 \\
47.4 \%\end{array}$ & $\begin{array}{l}40 \\
30.1 \%\end{array}$ & $\begin{array}{l}9 \\
6.8 \%\end{array}$ & & 2.2782 & .81047 \\
\hline $\begin{array}{l}\text { Appropriate measures are taken against } \\
\text { those who failed to comply with the tax } \\
\text { requirements }\end{array}$ & $\begin{array}{l}11 \\
8.3 \%\end{array}$ & $\begin{array}{l}58 \\
43.6 \%\end{array}$ & $\begin{array}{l}52 \\
39.1 \%\end{array}$ & $\begin{array}{l}12 \\
9 \%\end{array}$ & & 2.3534 & .69843 \\
\hline $\begin{array}{l}\text { Close and frequent contact with those } \\
\text { who failed to comply is made by the } \\
\text { organization }\end{array}$ & $\begin{array}{l}8 \\
6 \%\end{array}$ & $\begin{array}{l}58 \\
43.6 \%\end{array}$ & $\begin{array}{l}49 \\
36.8 \%\end{array}$ & $\begin{array}{l}18 \\
13.5 \%\end{array}$ & & 2.4887 & .77476 \\
\hline $\begin{array}{l}\text { Those complying with tax payment } \\
\text { expectations are recognized and } \\
\text { motivated to keep up complying }\end{array}$ & $\begin{array}{l}12 \\
9 \%\end{array}$ & $\begin{array}{l}49 \\
36.8 \%\end{array}$ & $\begin{array}{l}58 \\
43.6 \%\end{array}$ & $\begin{array}{l}14 \\
10.5 \%\end{array}$ & & 2.5789 & .79972 \\
\hline
\end{tabular}




\begin{tabular}{|c|c|c|c|c|c|c|c|}
\hline \multirow[t]{2}{*}{ Factors criteria on budget utilisation } & \multicolumn{5}{|c|}{ Response Rates } & \multicolumn{2}{|c|}{ Descriptive Statistics } \\
\hline & 1 & 2 & 3 & 4 & 5 & Mean & $\begin{array}{l}\text { Std. } \\
\text { Deviation }\end{array}$ \\
\hline $\begin{array}{l}\text { The tax payers know the consequences } \\
\text { of not complying with the tax } \\
\text { requirement }\end{array}$ & $\begin{array}{l}15 \\
11.3 \%\end{array}$ & $\begin{array}{l}51 \\
38.3 \%\end{array}$ & $\begin{array}{l}60 \\
45.1 \%\end{array}$ & $\begin{array}{l}77 \\
5.3 \%\end{array}$ & & 2.5564 & .80164 \\
\hline $\begin{array}{l}\text { Tax compliance represents good } \\
\text { governance in an era of transparency in } \\
\text { the budget utilization. }\end{array}$ & $\begin{array}{l}12 \\
9 \%\end{array}$ & $\begin{array}{l}54 \\
40.6 \%\end{array}$ & $\begin{array}{l}46 \\
34.6 \%\end{array}$ & $\begin{array}{l}15 \\
11.3 \%\end{array}$ & $\begin{array}{l}6 \\
4.5 \%\end{array}$ & 2.4436 & .76290 \\
\hline & & & & & & & \\
\hline
\end{tabular}

Source: Researcher's computation using SPSS (2018)

As shown in Table 3, concerning tax compliance in respects with Budget Utilizations the mean score of all the responses for all the items have been seen to be poor in their status.

This indicates that there is no clear information for the tax payers, no adequate time and facilities are provided to help tax payers, there are no clear responsibilities and penalties for non-compliance of tax in revenues office and Revenue office manager did not clearly defined measures of budget operationalization. The office is weak in taking measures against those who failed to comply with the tax requirements and less close \& frequent contact with those who failed to comply. As per the interview result the selected woredas revenue authority is not actively implementing the tax policy, did not provide awareness creation training to the tax payers continuously and weak in motivating active tax payer. This result in less tax revenue actually which vary from the expectation because of this budget shortage will be resulted.

Table 4 Respondents view on Inflation rate affecting budget utilization

\begin{tabular}{|c|c|c|c|c|c|c|c|}
\hline \multirow[t]{2}{*}{ Factors criteria on budget utilisation } & \multicolumn{5}{|c|}{ Response Rates } & \multicolumn{2}{|c|}{ Descriptive Statistics } \\
\hline & 1 & 2 & 3 & 4 & 5 & Mean & $\begin{array}{l}\text { Std. } \\
\text { Deviation }\end{array}$ \\
\hline $\begin{array}{l}\text { The budget utilization is planned by } \\
\text { forecasting the inflation rates of the } \\
\text { country. }\end{array}$ & $\begin{array}{l}12 \\
9 \%\end{array}$ & $\begin{array}{l}42 \\
31.6 \%\end{array}$ & $\begin{array}{l}41 \\
30.8 \%\end{array}$ & $\begin{array}{l}33 \\
24.8 \%\end{array}$ & $\begin{array}{l}5 \\
3.8 \%\end{array}$ & 2.8271 & 1.02626 \\
\hline $\begin{array}{l}\text { There have been unexpected rate of } \\
\text { inflation between plan and } \\
\text { implementation time of the budget. }\end{array}$ & $\begin{array}{l}26 \\
19.5 \%\end{array}$ & $\begin{array}{l}50 \\
37.6 \%\end{array}$ & $\begin{array}{l}40 \\
30.1 \%\end{array}$ & $\begin{array}{l}15 \\
11.3 \%\end{array}$ & $\begin{array}{l}2 \\
1.5 \%\end{array}$ & 2.3759 & .97391 \\
\hline $\begin{array}{l}\text { The budget allocated by the government } \\
\text { is in consideration of the country level } \\
\text { inflation rate. }\end{array}$ & $\begin{array}{l}8 \\
6 \%\end{array}$ & $\begin{array}{l}57 \\
42.9 \%\end{array}$ & $\begin{array}{l}37 \\
27.8 \%\end{array}$ & $\begin{array}{l}26 \\
19.5 \%\end{array}$ & $\begin{array}{l}5 \\
3.8 \%\end{array}$ & 2.7218 & .97198 \\
\hline $\begin{array}{l}\text { The Inflation rate in the country is } \\
\text { stabled. }\end{array}$ & $\begin{array}{ll}11 \\
8.3 \% \\
\end{array}$ & $\begin{array}{ll}74 \\
55.6 \% \\
\end{array}$ & $\begin{array}{l}24 \\
18 \% \\
\end{array}$ & $\begin{array}{l}24 \\
18 \% \\
\end{array}$ & & 2.4586 & .88344 \\
\hline $\begin{array}{l}\text { Inflation addressed by the government in } \\
\text { order to safeguard unplanned budgeting } \\
\text { at your organization level. }\end{array}$ & $\begin{array}{l}22 \\
16.5 \%\end{array}$ & $\begin{array}{l}43 \\
32.3 \%\end{array}$ & $\begin{array}{l}53 \\
39.8 \%\end{array}$ & $\begin{array}{l}15 \\
11.3 \%\end{array}$ & & 2.4586 & .90043 \\
\hline
\end{tabular}

\section{Source: Researcher's computation using SPSS (2018)}

As per the response of the respondents shown on table 4 above, the inflation rate is not strictly considered in budget preparation and utilization, there have been unexpected rate of inflation between plan and implementation time of the budget, the budget allocated by the government is in consideration of the country level inflation rate, the inflation rates of the country can be forecasted and inflation addressed by the government in order to safeguard unplanned budgeting at the revenues organization level. The results obtained from the analysis of the questionnaire regarding inflation rates were indicated that there is poor attention concerning the impact of inflation rate on budget utilization in public sectors. 
Table 5 Respondents view on Records, Reports, and Audit of Budget Users affecting budget utilization

\begin{tabular}{|c|c|c|c|c|c|c|c|}
\hline Factors criteria on budget utilisation & \multicolumn{5}{|c|}{ Response Rates } & \multicolumn{2}{|c|}{ Descriptive Statistics } \\
\hline & 1 & 2 & 3 & 4 & 5 & Mean & $\begin{array}{l}\text { Std. } \\
\text { Deviation }\end{array}$ \\
\hline $\begin{array}{l}\text { Your office keeps complete budgetary } \\
\text { records in accordance with the country's } \\
\text { financial administration proclamation } \\
\text { and regulations. }\end{array}$ & $\begin{array}{l}16 \\
12 \%\end{array}$ & $\begin{array}{l}48 \\
36.1 \%\end{array}$ & $\begin{array}{l}46 \\
34.6 \%\end{array}$ & $\begin{array}{l}13 \\
9.8 \%\end{array}$ & $\begin{array}{l}10 \\
7.5 \%\end{array}$ & 2.6466 & 1.06027 \\
\hline $\begin{array}{l}\text { Budget utilization is always implemented } \\
\text { based on full documents and evidences of } \\
\text { revenues office. }\end{array}$ & $\begin{array}{l}13 \\
9.8 \%\end{array}$ & $\begin{array}{l}47 \\
35.3 \%\end{array}$ & $\begin{array}{l}39 \\
29.3 \%\end{array}$ & $\begin{array}{l}25 \\
18.8 \%\end{array}$ & $\begin{array}{l}9 \\
6.8 \%\end{array}$ & 2.7744 & 1.07743 \\
\hline $\begin{array}{l}\text { Your office presents timely, explanatory, } \\
\text { and complete budget implementation } \\
\text { report }\end{array}$ & $\begin{array}{l}20 \\
15 \%\end{array}$ & $\begin{array}{l}32 \\
24.1 \%\end{array}$ & $\begin{array}{l}52 \\
39.1 \%\end{array}$ & $\begin{array}{l}23 \\
17.3 \%\end{array}$ & $\begin{array}{l}6 \\
4.5 \%\end{array}$ & 2.7218 & 1.06140 \\
\hline $\begin{array}{l}\text { The financial statement of your office is } \\
\text { audited regularly by an independent } \\
\text { auditor. }\end{array}$ & $\begin{array}{l}25 \\
18.8 \%\end{array}$ & $\begin{array}{l}43 \\
32.3 \%\end{array}$ & $\begin{array}{l}44 \\
33.1 \%\end{array}$ & $\begin{array}{l}21 \\
15.8 \%\end{array}$ & & 2.4586 & .97321 \\
\hline
\end{tabular}

\section{Source: Researcher's computation using SPSS (2018)}

The above table 5 indicates that the office did not keep record as per financial administration proclamation and regulations of the country, no sure about Expenditures are shown in appropriate account codes and Budget utilization is not implemented based on full documents and evidences of revenues office. The office are weak in presenting timely, explanatory, and complete budget implementation report and the financial statement is not audited regularly by an independent auditor.

\section{Regression Analysis}

In order to measure the effect of the structural, Policy, tax compliance, inflation and record related factors on the budget utilization of the selected public sectors the researcher has used multiple linear regressions and interpreted the results as follows.

Table 6 Model Summary

\begin{tabular}{|l|l|l|l|l|}
\hline Model & $\mathrm{R}$ & $\mathrm{R}$ Square & Adjusted R Square & Std. Error of the Estimate \\
\hline 1 & $.942^{\mathrm{a}}$ & .887 & .882 & .35389 \\
\hline
\end{tabular}

As it can be observed from the table 6 above there is strong association between the independent variables under consideration and the budget utilization as indicated by $\mathrm{R}$ accounting $94.2 \%$ rated to be strong positive. In addition to this the R-Square results showed that the sum total effect of these factors on the budget utilization accounts more than $88 \%$ showing that these factors together have this much influence on the budget utilization of these sectors.

Table 7 ANOVA

\begin{tabular}{|l|l|l|l|l|l|l|}
\hline \multicolumn{2}{|l|}{ Model } & Sum of Squares & df & Mean Square & F & Sig. \\
\hline \multirow{3}{*}{1} & Regression & 124.351 & 5 & 24.870 & 198.585 & $.000^{\mathrm{b}}$ \\
\cline { 2 - 7 } & Residual & 15.905 & 127 & .125 & & \\
\cline { 2 - 6 } & Total & 140.256 & 132 & & & \\
\hline \multicolumn{2}{|l|}{ a. Dependent Variable: Budget utilization } \\
\hline
\end{tabular}

Source: Researcher's computation using SPSS (2018)

The ANOVA table 7 above is all about the model fitness test for measuring the effect of these independent variables on the budget utilization of the sectors. As such, the significance level .000 shows that the $\mathrm{F}$ test is large enough to prove that the model is adequate to measure the effect of these factors on the budget utilization with lesser residuals provided. 
Table 8 Coefficients

\begin{tabular}{|c|c|c|c|c|c|c|}
\hline \multirow{2}{*}{\multicolumn{2}{|c|}{ Model }} & \multicolumn{2}{|c|}{ Un standardized Coefficients } & \multirow{2}{*}{$\begin{array}{l}\text { Standardized Coefficients } \\
\text { Beta }\end{array}$} & \multirow[t]{2}{*}{$\mathrm{T}$} & \multirow[t]{2}{*}{ Sig. } \\
\hline & & $\mathrm{B}$ & Std. Error & & & \\
\hline \multirow{6}{*}{1} & (Constant) & -.282 & .202 & & -1.394 & .166 \\
\hline & Structural Factors & .569 & .179 & .375 & 3.185 & .002 \\
\hline & Policy & -.370 & .065 & -.369 & -5.684 & .000 \\
\hline & Compliance & -.303 & .160 & -.225 & -1.891 & .061 \\
\hline & Inflation & 1.105 & .124 & .966 & 8.915 & .000 \\
\hline & Records & -.057 & .037 & -.047 & -1.563 & .121 \\
\hline
\end{tabular}

a. Dependent Variable: Budget utilization

\section{Source: Researcher's computation using SPSS (2018)}

From the coefficients table 8 above, it can be observed that structural factors, tax policy and inflation are the major significant factors affecting the budget utilization of these targeted public sectors of East Wollega Zones. Here we can see from the standardized coefficients that inflation is the most influential factor with the highest $96.6 \%$ possible effect on the budget utilization level showing that the more the inflation is the higher the budget utilized is. Inflation as such, is proved to affect the amount of budget utilized in higher degree. The other significant effect comes from the structural factors. The structural factors have been shown to have $37.5 \%$ effect on the level of budget utilized showing that the stronger the structural factors are the more the budget to be utilized is. Finally the other significant effect comes from the policy that the country and the sectors have towards the budget utilization. The policy has been shown to have $36.9 \%$ negative effect on the budget level utilized confirming the fact that the stronger the budget utilization policies are the lesser the budget utilized will be in these public sectors under consideration.

\section{Correlation Analysis}

In order to measure the degree of association between the factors and budget utilization the researcher has used Pearson correlation through the SPSS 20 version as follows.

\section{Table 9 Correlation Analysis}

\begin{tabular}{|c|c|c|c|c|c|c|c|}
\hline \multicolumn{8}{|c|}{ Correlations } \\
\hline & & $\begin{array}{c}\text { Budget } \\
\text { utilization }\end{array}$ & Structural & Policy & compliance & Inflation & Records \\
\hline \multirow{3}{*}{$\begin{array}{l}\text { Budget } \\
\text { utilization }\end{array}$} & \begin{tabular}{|l} 
Pearson \\
Correlation
\end{tabular} & 1 & $.728^{* *}$ & $.208^{*}$ & $.877^{* *}$ & $.920^{* *}$ & .017 \\
\hline & Sig. (2-tailed) & & .000 & .016 & .000 & .000 & .846 \\
\hline & $\mathrm{N}$ & 133 & 133 & 133 & 133 & 133 & 133 \\
\hline \multirow{3}{*}{ Structural } & \begin{tabular}{|l|} 
Pearson \\
Correlation
\end{tabular} & $.728^{* *}$ & 1 & $.742^{* *}$ & $.858^{* *}$ & $.851^{* *}$ & .038 \\
\hline & Sig. (2-tailed) & .000 & & .000 & .000 & .000 & .666 \\
\hline & $\mathrm{N}$ & 133 & 133 & 133 & 133 & 133 & 133 \\
\hline \multirow{3}{*}{ Policy } & \begin{tabular}{|l} 
Pearson \\
Correlation \\
\end{tabular} & $.208^{*}$ & $.742^{* *}$ & 1 & $.392^{* *}$ & $.398^{* *}$ & -.032 \\
\hline & Sig. (2-tailed) & .016 & .000 & & .000 & .000 & .715 \\
\hline & $\mathrm{N}$ & 133 & 133 & 133 & 133 & 133 & 133 \\
\hline \multirow{3}{*}{ compliance } & \begin{tabular}{|l} 
Pearson \\
Correlation \\
\end{tabular} & $.877^{* *}$ & $.858^{* *}$ & $.392^{* *}$ & 1 & $.959^{* *}$ & .033 \\
\hline & Sig. (2-tailed) & .000 & .000 & .000 & & .000 & .708 \\
\hline & $\mathrm{N}$ & 133 & 133 & 133 & 133 & 133 & 133 \\
\hline \multirow{3}{*}{ Inflation } & $\begin{array}{l}\text { Pearson } \\
\text { Correlation }\end{array}$ & $.920^{* *}$ & $.851^{* *}$ & $.398^{* *}$ & $.959^{* *}$ & 1 & .047 \\
\hline & Sig. (2-tailed) & .000 & .000 & .000 & .000 & & .590 \\
\hline & $\mathrm{N}$ & 133 & 133 & 133 & 133 & 133 & 133 \\
\hline \multirow{3}{*}{ Records } & \begin{tabular}{|l|} 
Pearson \\
Correlation \\
\end{tabular} & .017 & .038 & -.032 & .033 & .047 & 1 \\
\hline & Sig. (2-tailed) & .846 & .666 & .715 & .708 & .590 & \\
\hline & $\mathrm{N}$ & 133 & 133 & 133 & 133 & 133 & 133 \\
\hline
\end{tabular}

Source: Researcher's computation using SPSS (2018) 
As it can be seen from table 9 above it has been proved that there exists strong positive relation between structural factors and the level of budget utilization accounting for 0.728 this proves that the more tightly the structural factors the same level growth in the level of budget utilization will be. Inflation rate has been also shown to have strongest positive relation with the level of budget utilized showing that the inflation rate increase will result in increase in the level of budget utilization. The other factor having strong relation with budget utilization is that Tax compliance showing the raise in the level of tax compliance will have the ability to raise budget utilization in the same direction.

\section{Conclusion}

Based on the data collected from the respondents the researcher has analyzed reliable data from adequate samples and has reached on the following conclusions for the desired specific objectives.

The major factors affecting the utilization of budget in these sectors were identified to be Structural factors; inflation and budget related policy have significant effect on the level of budget utilization in East Wollega Zone selected public sectors while tax compliance and records keeping have shown insignificant effect on the level of budget utilization.

It has been proved that there exists strong positive relation between structural factors and the level of budget utilization. This proves that the more tightly the structural factors the same level growth in the level of budget utilization will be. Inflation rate has been also shown to have strongest positive relation with the level of budget utilized showing that the inflation rate increase will result in increase in the level of budget utilization. The other factor having strong relation with budget utilization is that Tax compliance showing the raise in the level of tax compliance will have the ability to raise budget utilization in the same direction.

\section{Recommendations}

Being based on the conclusions made after the summarization and analysis of data here the researcher recommends some general and specific recommendations as follows.

- The structural factors are the basic factors that the respective organizations can improve, and as such the organization should train and convince all the departments or units to plan act together especially in utilizing the budget of the respective organizations.

- Whenever planning the budget for specific year the organizations should strictly consider the inflation rates forecasts of the country as it could have greater effect on the level of budget utilization.

- Responsibility and accountability should be given to each level unit's for effective utilization of their budgets.

- Planning procedure should be shortened and there should be coordinated effort with other departments.

- In order to achieve efficient ways of budget utilization the office must follows:

$\checkmark \quad$ Improve a time base plan of budget

$\checkmark \quad$ Improve the officer skills by providing short term training based on their gap assessed.

$\checkmark \quad$ Adopting strong and continuous monitoring and evaluation of budget

$\checkmark \quad$ Facilitating the pre-condition to use budget

- Advanced technology must be adopted for the office in order to run the budget efficiently and on specific period.

- A government policy that is all inclusive should be drawn to assist in budget utilization operationalization in the study area

- The research of this study recommends the following areas for further research; how organizational behavior and politics can influence budgetary utilization in major devolved governments and challenges facing implementation of devolved governance in allocation of devolved funds.

\section{References}

Abshiro, E. (2014). Assessment of budget implementation and control system in case of KolfeKeranyosubcity. FDRE., F. D. (2009). The federal government of Ethiopia financial administration proclamation No. 190/2010. Addis Ababa: Federal NegaritGazeta.15th Year, No. 56, 6th August 2009.

Kajuju, C. (2012). Factors that affect budget utilization by government ministries in Kenya.University of Nairobi. KetemaMuluneh (2015), Assessment of Budget Preparation and Utilization: Case of Addis Ababa City Administration Health Bureau, Addis Ababa University, Ethiopia,

Muluneh, K. (2015). Assessment of Budget Preparation and Utilization: Case of Addis Ababa City Administration Health Bureau. 36.

Rotich, C. K. (2015). Factors affecting budget utilization Kericho county government in Kenya. International Journal of Economics, Commerce and Management, 26,27. 
Schiavo-Campo, S. \&. (1999). Managing Government Expenditure. Asian Development Bank.

Tafa, D. (2016). Intrinsic Factors Affecting Budget Utilization in Ethiopian Public Universities. Journal of Economics and Sustainable Development . 